\title{
リポソーム封入による制癌剤の効果増強に関する基礎的研究
}

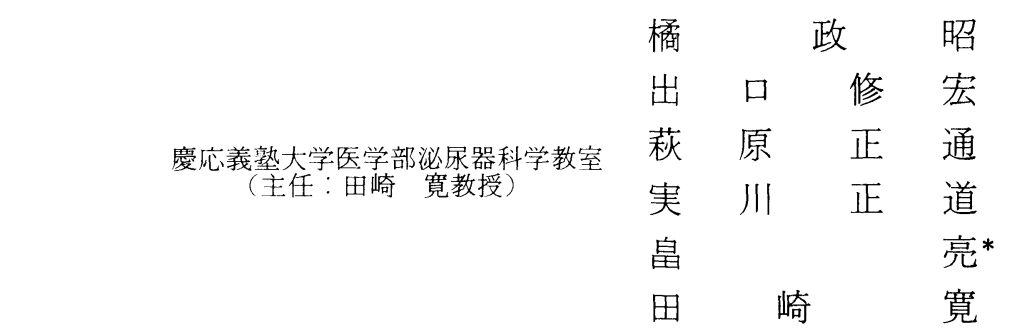

\section{ENHANCEMENT OF ANTITUMOR EFFECT ON UROLOGICAL CANCER IN VITRO AND IN VIVO BY DRUGS ENTRAPPED IN LIPOSOME}

\author{
Masaaki Tachibana, Nobuhiro Deguchi, Masamichi Hagiwara, Seido Jitsukawa, \\ Makoto Hata* and Hiroshi Tazaki \\ Dept. of Urology, School of Medicine, Keio University \\ *Dept. of Urology, National Defence Medical College
}

Liposome is a bilayered phospholipid vesicles, and was originally developed as a model for biomembranes. Liposome has attracted attention in recent years as a potential carrier of anticancer drugs thereby enhancing the therapeutic effect. This study was designed to clarify the following problems associated with clinical application of liposome in future.

1) The influence of liposome-entrapped anticancer drugs on cytotoxic activity in in vitro system.

2) The effect of liposome-entrapped anticancer drugs in the host tissues.

3) The in vivo therapeutic efficacy of liposome-entrapped bleomycin in the treatment of testicular tumor transplanted in nude mice.

For cytotoxicity test, KU-2 cells, dervived from human renal cell carcinoma were used. Effect of free and liposome-entrapped bleomycin on the growth of KU-2 cells was determined. Enhanced effect was noted in the latter group. Also effect of free and liposome-entrapped bleomycin on the cell cycle traverse of KU-2 cells was determined by means of flow microfluorometry. Obvious effects of $\mathrm{G}_{2}$-block was noted in liposome-entrapped bleomycin.

Therapeutic effect of free and liposome-entrapped bleomycin on the testicular tumor bearing nude mice (KUNU-1) was examined. Antitumor effects of bleomycin was enhanced by entrapment of bleomycin into liposome, mean growth rates of the tumor by administration of free and liposomeentrapped bleomycin at day 5 were $91.1 \pm 8 \%$ and $76.1 \pm 14 \%$, respectively.

Bleomycin, either free or liposome-entrapped, was injected into the peritoneal cavity of KUNU-1 mice in a dose of $5 \mathrm{mg}$. When liposome-entrapped bleomycin was given, increase in the concentration of bleomycin was sixfold in the spleen; threefold in the liver; twofold in the kidney and one and half fold in the lung.

These results indicate that liposome entrapment modified the pharmacokinetics and enhanced the anticancer activity of the drug mediated by slow delivery rather than providing selective cytotoxic effect of the drug to tumors.

要旨：癌化学療法剂の効果増強を計る目的で制癌剂のリポソーム封入を行ない, その増強効果につき検

討した。

* 現 防衛医科大学校泌尿器科 
ヒト腎癌培養細胞（KU-2）に対する殺細胞能の実験では, bleomycin, methotrexate,において, リポ ソーム封入側に, より強い増殖抑制効果を認めたが, cytosine-arabinoside, cis-platinum, では, free 薬 剂との間に, 明らかな差を認めなかつた. Flow microfluorometryにより, KU-2 細胞の細胞周期に及ぼ す影響を検討すると, bleomycin 封入リポソームで, free-bleomycin に比し, $\mathrm{G}_{2}$-block effect の増強が 観察された。そこで, リポソーム添加 medium 中で培養した KU-2 細胞を電顕下に観察すると, 細胞質 内に, 多重層構造を呈するリポソームが認められ, 培養細胞内へのリポソームの取り込みが証明された。 ヌードマウス可移植性ヒト睪丸腫瘍(KUNU-1) に対する抗腫瘍効果を, $5 \mathrm{mg}$ の free 拈よび，リポソー 厶封入 bleomycinにて, 比較検討すると, 腹腔内投与 5 日後の腫瘍の size は, free-bleomycin 群が $91 \pm$ $8 \%$ に対し, リポソーム封入群は $76 \pm 14 \%$ と, リポソーム封入群により強い腫瘍増殖抑制を認めた. しか しながら, この時の, bleomycinの組織内濃度を測定すると, リポソーム封入群で, 肝, 脾に約 $3 \sim 6$ 倍の薬剤濃度を認めるが, 腫瘍内濃度では, 両者に差を認めなかつた。したがつて, この治療効果増強 は, bleomycinのリポソーム封入にともなら徐放性によると考えられた。

\section{緒 言}

近年, 癌化学療法の進歩とともに, 多くの制癌剂が 開発され，その効果も目覚しく向上してきているが， いまだ充分とは言えない。これらの薬剤濃度の体内特 続性の久如にあると思われる。薬剂を目的とする藏器 や細胞に選択的に到達させるため, 従来より, 各種の 担体物質が考案されてきている。最近, 人工脂質膜の 微小胞球である, リポソームが注目され, 制癌剂の封 入による種々の実験的検討が進められている。著者ら は, このリポソームに, 各種制癌剂を封入し, 以下の 項目につき実験を行ない, 将来の臨床応用への可能性 を導いた。

(1) in vitroに打けるリポソーム封入制癌剤の殺 細胞能の検討.

(2) in vivo に抢けるリポソーム封入制癌剤の体内 分布.

（3）ヌードマウス可移植，ヒト冝丸腫瘍に対する bleomycin 封入リポソームの抗腫瘍効果の検討.

\section{I. 方 法}

(1) リポソーム封入薬凧の作成.

卵黄レシチン PL-100* (キューピー研究所)

cholesterol (CHOL) (東京化成工業)

stearylamine (SA) (東京化成工業)

の 3 種の脂質を $\mathrm{PC} / \mathrm{CHOL} / \mathrm{SA}=7: 2: 1(\mathrm{~mol}$ 比)にて調製し，クロロホルム溶液中に溶解する。100 $\mathrm{ml}$ の心臓型フラスコ中に, この溶解液を入れ, ロータ リーエバポレーターに接続, フラスコ内面に均一な厚

* phosphatidylcholine (PC): phosphatidylethanolamine : sphingomyelin : ribophosphatidylcholine $=40: 4.8: 1.6: 3.5(\mathrm{~mol}$ 比 $)$
さの薄膜を形成するため，デシケータに入れ，吸引ポ ンプにて一夜吸引する。次に薄膜を形成したフラスコ 内に, ガラスビーズ(日本クロマト工業 mesh 80-100) をスパテール $(\phi 7 \times 10 \mathrm{~mm}) 3$ 杯と, 薬剤水溶液 $5 \sim 10$ $\mathrm{ml}$ を加光, Thermo-Mixer で激しく擋拌する。このこ とにより, フラスコ内の薄膜は, ガラスビーズにより はがされ，リポソームの懸濁液が得られる。この溶液 を, $0.075 \mathrm{M} \mathrm{NaCl}$ と0.075 M KClの等量液を適量使 用し, ガラスビーズを除去, 更に懸濁液を遠心 $(14,500$ $\mathrm{rpm}, 13,000 \mathrm{G}, 4^{\circ} \mathrm{C}, 20$ 分) すると, リポソームの白沈 が得られる。上清をすて, 更に遠心にてリポソームを 洗浄, 上記の $\mathrm{NaCl}, \mathrm{KCl}$ の等量液中に懸濁, $4{ }^{\circ} \mathrm{C}$ に 保存した。

(2) bleomycin : $4{ }^{\circ} \mathrm{C}, 0.075 \mathrm{M} \mathrm{NaCl} \prec 0.075 \mathrm{M}$ $\mathrm{KCl}$ の等量液中に浮遊された薬剤封入リポソームを 遠沈（14.500 rpm, $13,000 \mathrm{G}, 4^{\circ} \mathrm{C}, 20$ 分）し, 上清液 をすて，下層液の一定量をとり，クロロホルムを加光 てリポソームを分解し, さらに0.1 M リン酸 buffer (PH 6.8)を加光抽出拉よび希釈を行ない，これを遠心 分離後, 上層液を日本抗生物質医薬品基準, 塩酸ブレ オマイシン, 力価試験法-II, 標準曲線法 ${ }^{1)}$ と準じて力価 測定を行なつた。

(b) cis-platinum diammine dichloride (CPDD): bleomycin と同様にクロロホルムで処理後, 日立17030原子吸光光度計, Hallow cathode lamp L 233$78 \mathrm{NU}$ ランプ, 2659 ・5 ̊の分析波長にて測定した.

(c) cytosine-arabinocide (ara-C)：クロロホルム にて処理後, 蒸留水にて稀釈し, これに濃塩酸 $5 \mathrm{mcl}$ を 添加, PHを 2 付近にする. これを分光光度計 (Gilford spectrophotometer 24D）で吸収波長 $280 \mathrm{~nm}$ にて計測 した. 
(d) methotrexate (MTX): クロロホルムで処理 後分光光度計（日立100-10）吸収波長300nm 飞て測定 し, standard MTX solusion (Unicam) に上り, 薬 剂量を求めた。

(a)〜（d）の薬剤の取り达み率は次式に求めた。 $\frac{\text { リポソーム内の薬剂取り込み量 }}{\text { 封入するのに用いた水溶液中の薬剂量 }} \times 100$

(3) in vitroに打ける殺細胞効果

ヒ卜腎癌由来培養細胞株(KU-2) (10\% fetal bovine serum 加, Eagle MEM 中, $5 \% \mathrm{CO}_{2}$ air, $37^{\circ} \mathrm{C}$ そて 培養）を multi well culture plate well 移植， 3〜4日後に, free 招よび薬剂封入リポ ソームを培養液中に添加し, 持続接触の形で作用させ, 24時間ごとの生理細胞数を計測した。薬剤封入りポ ソームはfree 薬剤を濃度を一定にするため, リポソー ムにとりこまれず freeのままで残つた薬剤を含めて, 等量の薬剤溶液になるようにして使用した。

bleomycin については, flow microfluorometry そ より，細胞周期に和よぼす影響を検討するため， $1 \times$ $10^{5}$ 個 $/ \mathrm{ml}$ の KU-2 細胞を plastic シャーレ (Falcon $\phi$ $8 \mathrm{~cm})$ に移植，4〜5 日後 $10 \mathrm{mcg} / \mathrm{ml}$ の free 抒よび, リポソーム封入 bleomycin 持続接触させ, 薬剤接触 3 日後の細胞の DNA 含量の分布を観察した。

(4) in vivoに抢ける薬剂封入リポソームの体内動 態。

ヌードマウス可移植性ヒト等丸腫瘍 (KUNU-1, ter- ato carcinoma)は, その畽瘍組織索細切し, 約500mg の腫場片を trocar 針にて, ヌードマウス側背部皮下に 移植，10１4日後，腫瘍が確実に増殖することを確認 し, $5 \mathrm{mg} /$ 頭の, free 括よびリポソーム封入し bleomycin（封入率10１2％) を腹腔内に 1 回投与し， 薬剂投与後, 12 時間, 24 時間の各臓器拈よび腫瘍組織 の bleomycin 濃度を, bio-assay にて求めた。

（5） in vivo 比打可抗腫瘍効果.

前述の条件にて処理した KUNU-1, 担癌ヌードマウ スに, $5 \mathrm{mg} /$ 頭の free 蛙よびリポソーム封入 bleomycin を腹腔内に 1 回投与後, 腫瘍径を毎日測定 した。腫煌径は, 最長 ( a ) 高さ ( b ) を計測し, $a \times b^{2}$ / 2 を腫瘍量とし, 薬剤投与時の腫瘍量を 100 として算定 した。

\section{II. 結 果}

（1）薬剤のリポソーム封入量呿よび安定性

前述の方法で作製したりポソームを透過型電子顕微 鏡にて観察すると，大小不同，多重層構造を呈する微 小胞が，観察された(図 1). 薬剂封入率は, bleomycin 12\%, CPDD $4 \%$, Ara-C 13\%, MTX 3\% と, 薬剤 により，封入率に多少の差を認めた。薬剤入りポンー 么を，生理食塩中， $37^{\circ} \mathrm{C}$ 亿 incubateした場合の release rateを計測すると, BLM, CPDD, Ara-C, 共 に, 24時間後でも $80 \%$ 程度, リポソーム内に保持され て和り，比較的安定であつた（図 2 )。

(2) in vitroに和ける殺細胞効果

図 1 重層する膜より成り立つ, リポソーム電䫓像

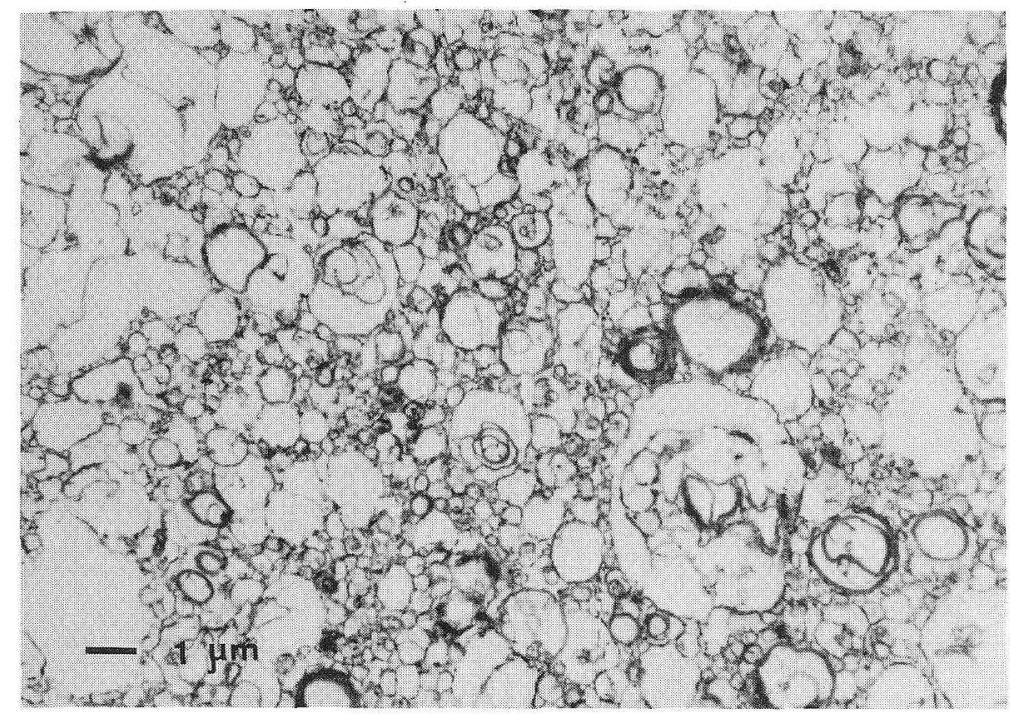


$1 \times 10^{4} / \mathrm{ml}$ の KU. 2 細胞に対し Eagle MEMを封 入したリポソーム浮遊液を $10 \mathrm{mcl} / \mathrm{ml}$ 培養液中に混入 し, KU-2 細胞の増殖を検討すると, 正常培養条件での control 群と,リポソーム封入群の間に差を認めず, リ ポソーム単独では, 増殖抑制が起こらないことが確認 された（図 3 ).

$\mathrm{BLM}, 10 \mathrm{mcg} / \mathrm{ml}$ の濃度における, KU-2 細胞の增殖 曲線を検討すると, 薬剂作用後 4 日目の生細胞数は, free-BLM で $87.6 \%$ ポソーム封入 BLM では, $74.5 \%$ と、リポソーム封入側により強い増殖抑制効果 を認めた（図 4 ）。これを, flow microfluorometry に より，細胞周期におよぼす影響についてみると，薬剤 接触 3 日目において, $G_{2}+M$ fraction が, free-BLM

困 2 Release rate of drugs from liposome

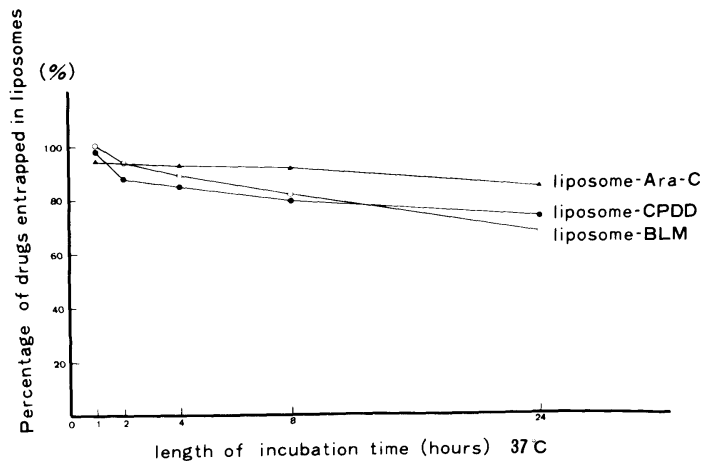

図 3 Effect of liposome vesicles on the growth of $\mathrm{KU}-2$ cells in vitro

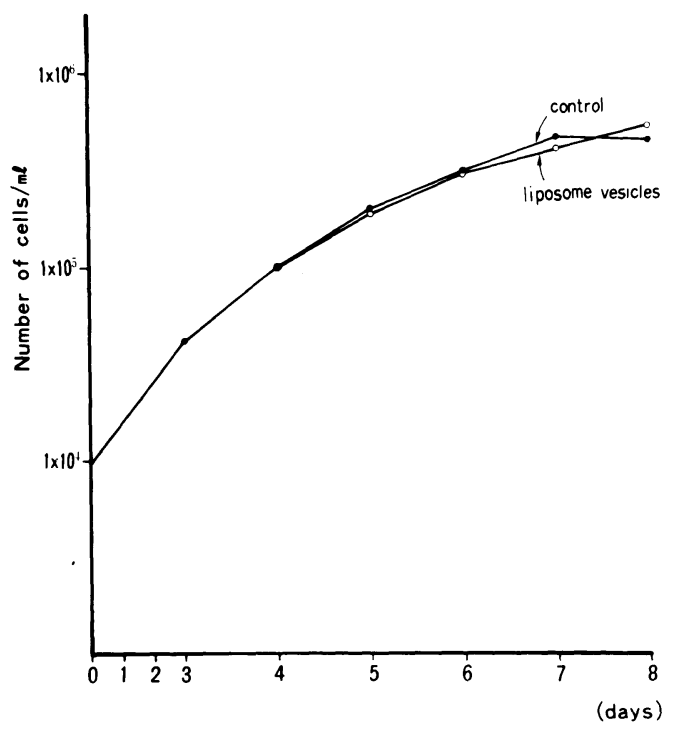

図 4 Effect of free or liposome-entrapped bleomycin on the growth of KU-2 cells in vitro

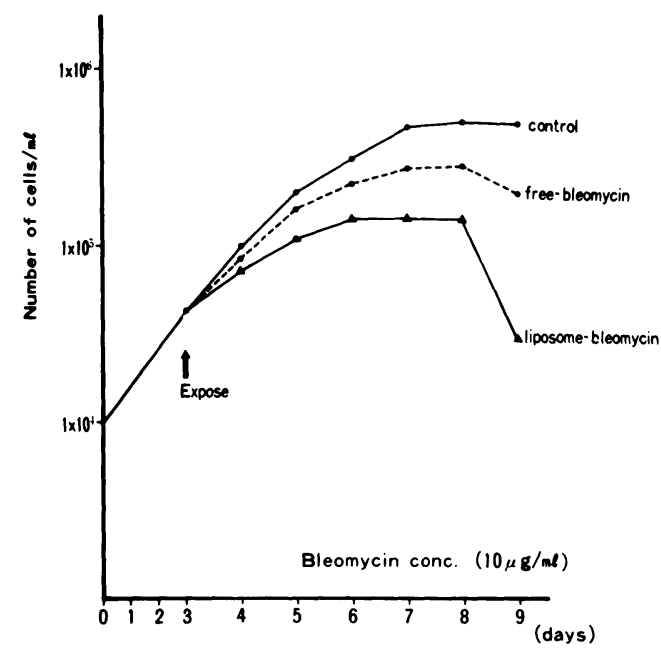

で $22 \%$, リポソーム封入 BLM で $27.5 \%$ と,リポソーム 封入側に, $\mathrm{G}_{2}$-block effect の増強されていることが観 察された（図 5 )。Ara-Cに招いては， $2 \mathrm{mcg} / \mathrm{ml} ， 10$ $\mathrm{mcg} / \mathrm{ml}$ の濃度では, free 抢よびリポソーム封入側の 間に明らかな殺細胞効果の差を認めないが(図 6 )，6 $\mathrm{mcg} / \mathrm{ml}$ に打いては, リポソーム封入に著しい増殖抑 制を認めた(図 7 ). CPDD, では, $2 \mathrm{mcg} / \mathrm{ml}$ の濃度で, リポソーム封入側に, 強い増殖抑制を認めたが(図 8), $5 \mathrm{mcg} / \mathrm{ml}, 10 \mathrm{mcg} / \mathrm{ml}$ の濃度では, 両者共に, 著しく増 殖が抑制され free および，リポソーム封入側との間 に, 差はみられなかつた。同様に, MTX の KU-2 細胞 間に対する殺細胞能を検討すると，free-MTXでは, $5 \mathrm{mcg} / \mathrm{ml}, 20 \mathrm{mcg} / \mathrm{ml}$ の濃度のいずれにおいても増殖 抑制効果は低く, 両群間に, 明らかな差は認めなかつ たが, liposome-MTX では，共に著明な増殖抑制を示 し，リポソーム封入による，殺細胞効果の増強を示し た（図 9 ).

培養細胞に対する，リポンーム球の作用を検討する ため, 透過型電子顕微鏡にて，リポソーム接触 24 時間 後の KU-2 細胞を観察すると, 細胞質内に多重層構造 を呈する, リポソーム球が観察され，細胞内への取り 込みが証明された（図10）。

（3）in vivoに打訬薬剂封入リポソームの体内動 態

$5 \mathrm{mg}$ の free およびリポソーム封入 BLM を腹腔内 投与した際の, 薬剂投与 24 時間後の各種臟器における BLM 組織内濃度は, リポソームBLM に扔いて, 肝に 
図 5 Effect of free \& liposome-entrapped bleomycin on the cell cycle traverse of KU-2

CH 204: CTS 800: INT 405
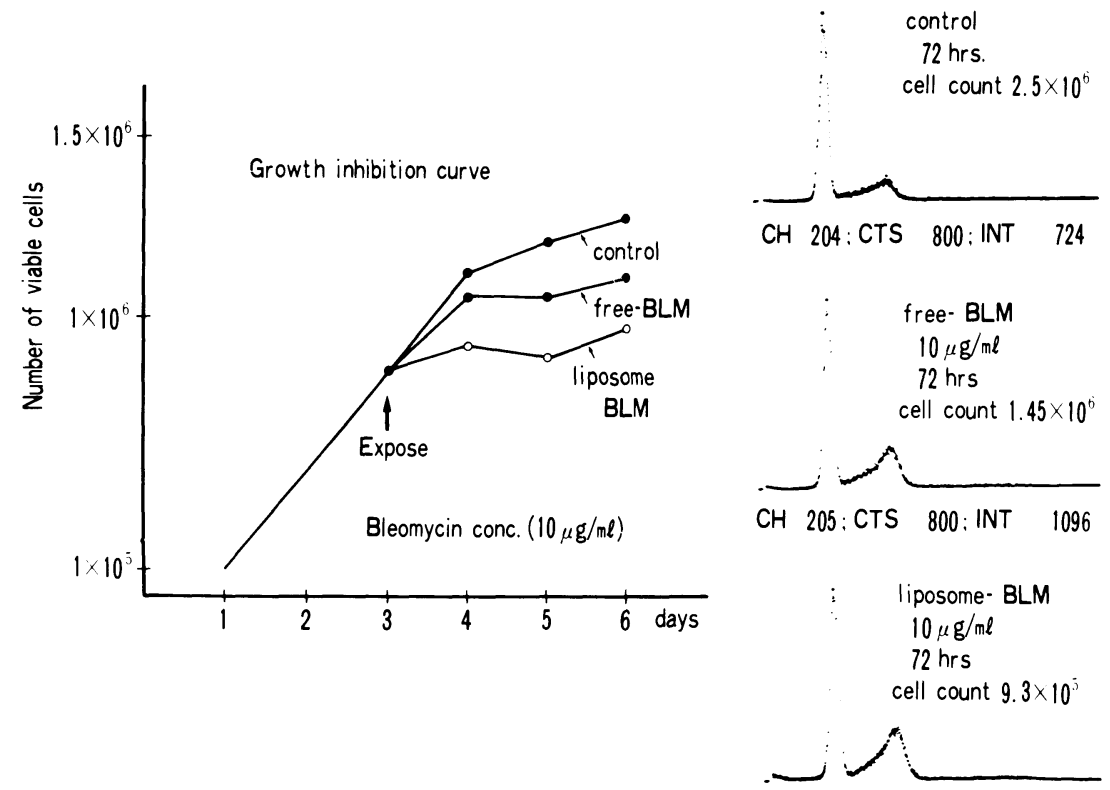

図 6 Effect of free or liposome-entrapped ara-C on the growth of KU-2 cells in vitro

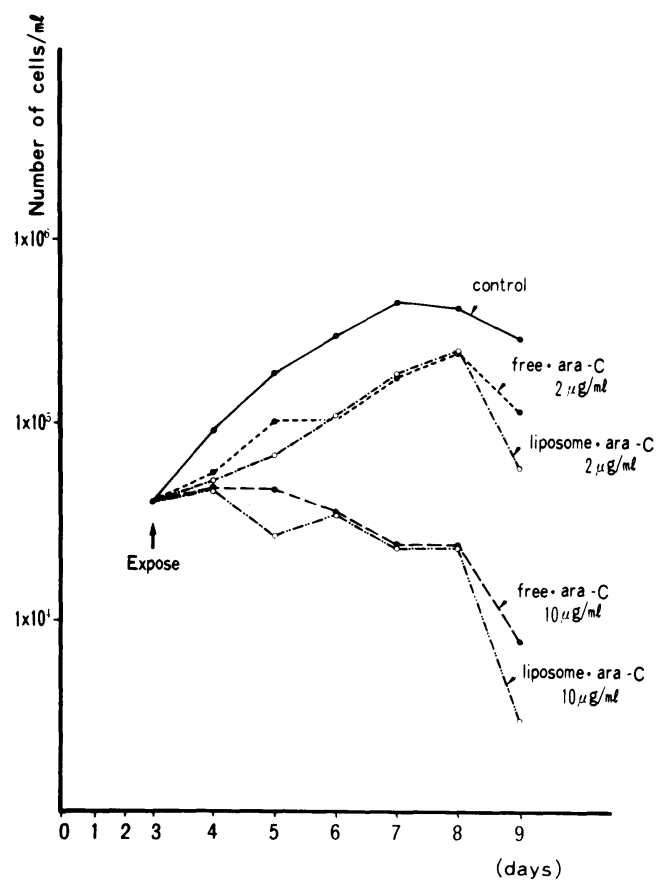

図 7 Effect of free or liposome entrapped ara-C on the growth of KU-2 cells in vitro

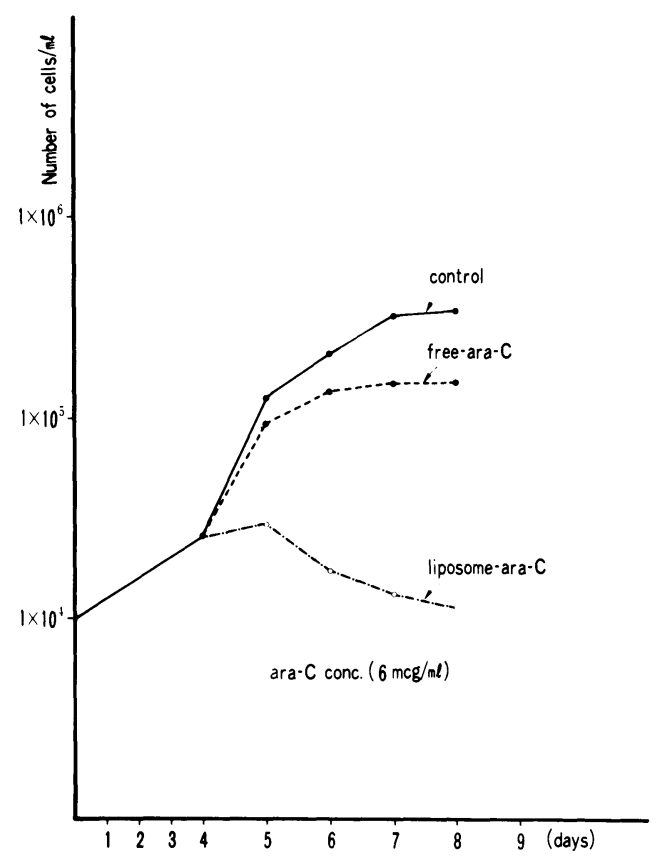


図 8 Effect of free or liposome-entrapped CPDD on the growth of KU-2 cells in vitro

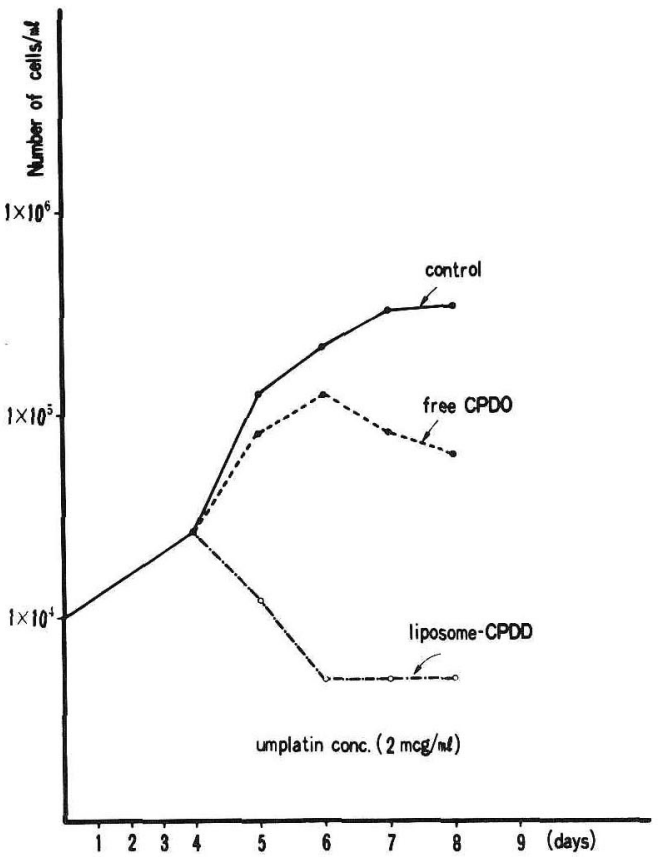

3 倍, 脾に5.8倍と, リポソーム BLM に持いて, 高值 を認め，リポソーム BLM が網内系に集積する傾向を 認めた。しかしながら腫瘍組織ではfree 拉よびリポ ソーム封入側，共に低值であつた（図11）。
図 9 Effect of free or liposome-entrapped MTX on the growth of KU-2 cells in vitro

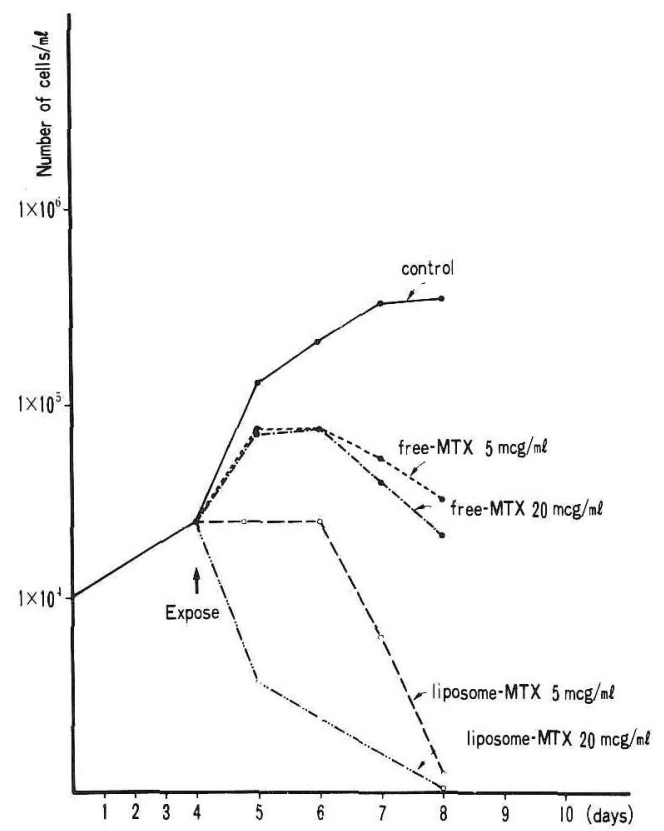

(4) in vivoにおける治療効果

ヌードマウス可移植性ヒト圅丸腫瘍 (KUNU-1) に 対する free 扣よびリポソーム封入 BLM の治療効果 に対する検討では, 薬㓝投与後 5 日後の腫瘍サイズで,

図10 KU-2の細胞質内に，多重層構造を示す，リポソームが多数認められた。

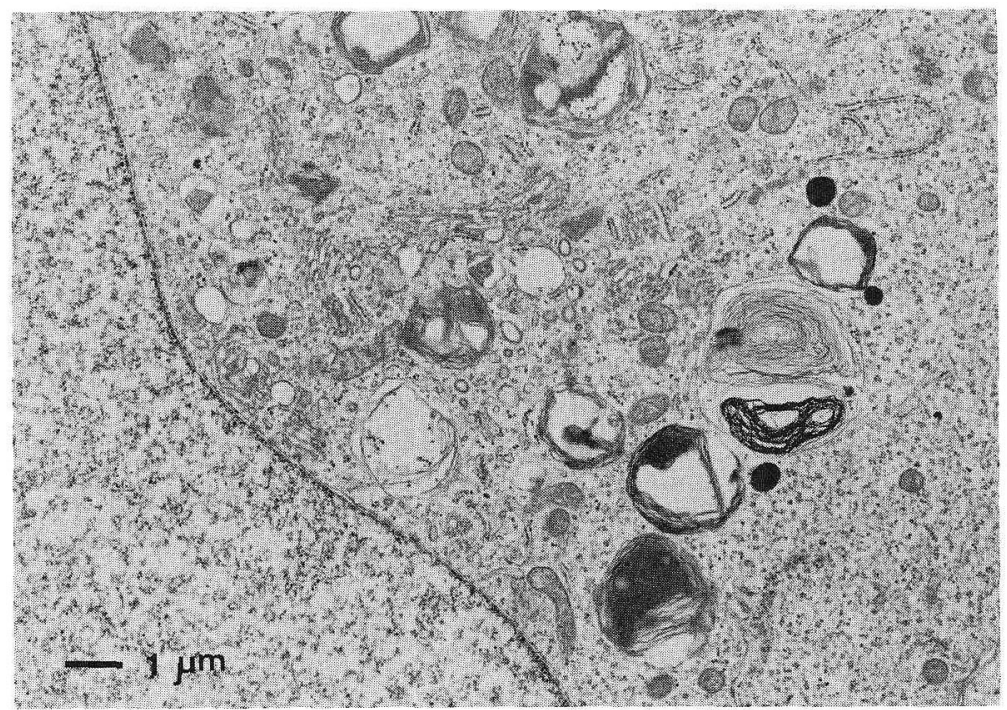


図11 Concentration of bleomycin in the tissues

\begin{tabular}{l|c|c|c|c} 
& \multicolumn{2}{|c|}{12 hours after injection } & \multicolumn{2}{c}{24 hours after injection } \\
\cline { 2 - 5 } & free-BLM & Liposome-BML & free-BLM & Liposome-BLM \\
\hline Liver & $0.14 \pm 0.09$ & $0.36 \pm 0.09$ & $0.12 \pm 0.045$ & $0.36 \pm 0.09$ \\
Spleen & $0.50 \pm 0.18$ & $3.3 \pm 1.2$ & $0.42 \pm 0.15$ & $3.0 \pm 0.26$ \\
Kidney & $0.36 \pm 0.09$ & $0.66 \pm 0.3$ & $0.32 \pm 0.045$ & $0.5 \pm 0.07$ \\
Lung & $0.36 \pm 0.05$ & $0.54 \pm 0.05$ & $0.34 \pm 0.054$ & $0.42 \pm 0.044$ \\
Bone & 0.1 & 0.1 & 0.1 & 0.1 \\
Brain & $<0.1$ & $<0.1$ & $<0.1$ & $<0.1$ \\
Tumor & $0.175 \pm 0.09$ & $0.2 \pm 0.08$ & $0.2 \pm 0.1$ & $0.17 \pm 0.058$ \\
Blood & $<0.1$ & $<0.1$ & $<0.1$ & $<0.1$ \\
\hline
\end{tabular}

図12 Growth rate of the testicular tumor transplanted to the nude mice

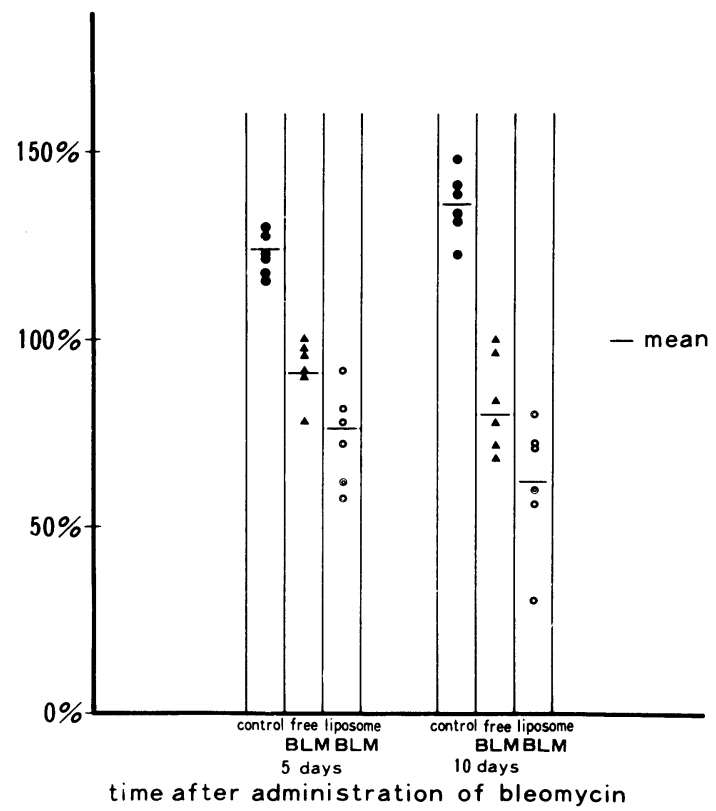

free-BLM は，91.1土8\%であつたが，リポソーム封入 群では, $76.1 \pm 14 \%$ と, リポソーム封入群により強い 腫瘍縮小効果を認めた（図12）.

\section{III. 考 案}

リポソーム膜の作製にあたつては，できるだけ均一 で安定性のあるものを作るため, 種々の工夫がなされ, 現在のところ，その基剤として, phosphatidylcholine (PC)が多く使用されている。これは PC が比較的自然 界に多く，得やすいこと，物性研究が進んでいること などがその理由として挙げられる。また小胞球の安定 化に寄与すると考えられるコレステロールの添加 ${ }^{21}$,
リポソーム表面に帯電するための, Deamer 法4), Papahadjopoulos 法 ${ }^{5)}$ 開発, 均一な一枚膜リポソー ムを作成するための超音波処置など6), 目的に応じた， より安定なリポソームの作製のための努力が重ねられ ている、著者らは Kinsky 7)らの方法に準じて, リポ ソームを作製したが，薬剤封入率は 4 〜 13\%, release rateは, 24 時間後で $20 \sim 30 \%$ と, 比較的安定な, 薬剤 封入リポソームが，作製されたものと考兄られる.

in vitroに拈ける殺細胞効果に対するリポソームの 影響を検討した結果では，BLM, MTXにおいて，明ら かなリポソーム封入による細胞増殖抑制効果の増強を 認め, さらにリポソーム封入 BLM においては, flow microfluorometry により, BLM の $\mathrm{G}_{2}$ block effect $の$ 増強を確認しており，この殺細胞効果が，リポソーム 封入による薬剂自身の効果増強のためであると考兄 る. Mayhew ${ }^{8)}$ によれば, ara-C 封入リポソームでは, L1210 細胞に対する殺細胞効果は, free ara-C との間 に差を認めなかつたとする報告があり，一方， Papahadjopoulos $^{9}$ らにより, アクチノマイシンDの 場合, in vitroで, リポソーム封入化による効果増強を 示す結果が示されて拈り統一された結論はでていな い. 著者らの実験では, ara-Cの場合，その薬剤濃度を 序々に増して行くと, リポソーム封入側に，低濃度で 強い増殖抑制を認めて招り，in vitroに拈いても，その 効府増強を示しているものと考える. この殺細胞効果 の増強される理由として, まず薬剤の不活性化の抑制 が挙げられる、たとえば, BLM の場合, マウスの組織 乳剂と薬剂を混合し, incubateすると, 肝, 脾, 睪丸, 腎組織では，短時間でかなりな程度に不活化が起こる ことが知られて和り ${ }^{10)}$, この不活化が, リポソーム封入 により妨げられるものと思われる. 次に細胞内への薬 剤の取り込みの増加が考えられる。この点に関して, Papahadjopoulos ${ }^{11)}$ Martin $^{12)}$, 前述の Mayhew ${ }^{8)}$ ら諸 家により, 薬剤の細胞内への取り込みが, リポソーム 封入化により, free の薬剂と培養細胞とを接触させた 場合に比し，著明に増加する報告がされている。この ような, 薬剤の細胞内取り込みを増加させる機序, つ まり，細胞とリポソームとの相互作用に関しては明ら かでないことが多く，吸着によるとするもの ${ }^{13)}, 6$ - カ ルボキシルフルオレッセンを使用した実験結果によ り, 融合 (fusion) とするもの ${ }^{14)}$, endocytosisにより 細胞内に入るとする説 ${ }^{15) 16)}$, がある. 著者らの, 培養細 胞にリポソームを作用させた後の電顕観察では, 多数 のリポソームが細胞内に証明されており, 培養細胞の 
ような, endocytic activity の高まつている状態では, リポソームは, endocytosisにより細胞内に取り込ま れるものと考える.

in vivoに打ける薬剤封入リポソームの体内動態に 関しては，網内系に集積することが多くの実験系によ り明らかにされており，著者らの KUNU-1を使用し た実験でも, 同様の結果を得た。McDougall ${ }^{17)}$, Dunnick $^{18)}$ らの, 腹腔内投与により, 網内系への移行が 減少するといら報告や，リポソームの大きさ，電荷等 によつても, その体内分布に変化が生じるよらである。 いずれにしても，リポソームの単独投与では，標的細 胞に薬剤を特異的に取り込ませることは不可能であ $\eta$, Uchida, ${ }^{19)}$ Yatvin ${ }^{20)}$, Leserman ${ }^{21)}$, 等により, 標 的細胞への薬剂の取り込みを高めるための種々の工夫 がなされている。

in vivo に招ける抗腫瘍効果については, リポソーム 封入化による薬剤の治療効果増強を示す結果が, $\mathrm{BLM}^{22)}$, Ara-C ${ }^{23)}, \mathrm{MTX}^{24)}, \mathrm{ACD}^{25) 26)}$, に扔いて, 諸

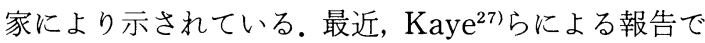
は, Ridgway osteosarcoma（ROS）移植 AKR マウ スに対し, phase non specificは薬剂である actinomycin $\mathrm{D}$ と, phase specific な methotrexate の 2 種の薬剤に対して, リポソーム封入化による, 抗腫 瘍効果を検討したところ, methotrexate に打いては, free-methotrexate より, 腫瘍増殖抑制の増強捻よび 正常組織に対する毒性の増加を認めたのに対し， actinomycin Dでは, free actinomycinより, 腫瘍増 殖抑制効果の減弱，正常組織への毒性低下を認めた実 験系を示し，薬剤の体内分布と考兄併わせて， methotrexate 封入リポソームの抗腫瘍効果増強は, 徐放性 によるものと結論している。著者らの実験結果でも, リポソーム封入による腫瘍組織内濃度が, free-BLM に対し，差を認められないことより，in vivoに打ける bleomycinのリポソーム封入化による抗腫瘍効果の増 強は，徐放性によるものと考学る。したがつて，現在 のところ, 薬剤のリポソーム封入による，抗腫瘍効果 増強は, phase specific な薬剂に限り有効であると考学 られる。

以上, 癌化学療法に抒ける薬剤修飾法として, 薬剤 のリポソーム封入化は，その有力な一手法と考光られ るが，さらに標的細胞に対する選択性を保持させるた めの研究が必要と考兄られた ${ }^{28)}$.

\section{IV. 結 語}

(1) phosphatidylcholin/cholesterol/stear- ylamine $=7: 2: 1$ の 3 種の脂質により, リポソー ム封入制癌剂を作成した。

(2) ヒ上腎癌培養細胞株（KU-2）に対する殺細胞効 果は, bleomycin, methotrexate,に抒いて, リポソー ム封入化により增強された。

(3) ヌードマウス可移植性ヒト睪丸腫瘍 (KUNU1)に対する腫瘍増殖抑制効果は, free-bleomycin に比 し,リポソーム封入 bleomycin で増強された。

(4) KUNU-1に対し, free 抢よびリポソーム封入 bleomycin を膜腔内投与後, 12時間, 24 時間の各種臓 器の bleomycin 濃度を比較すると, リポソーム封入群 で, 脾, 肝, 腎に颃いて free-bleomycin に比し高值と 認めた。しかし, 腫瘍内 bleomycin 濃度には差がなか つた.

(5) 以上の結果より, bleomycinのリポソーム封入 に伴う, 抗腫瘍効果の増強は, 徐放性によるものと考 光た。

\section{文献}

1）日本公定書協会監修：日本薬局方解説書. 第十改 正．E48一-51，廣川書店，東京， 1981 .

2) Papahadjopoulos, D., Cowden, M. and Kimelberg, H.: Role of cholesterol in membranes, effects on phospholipid protein interactions, membrane permeability and enzymatic activity. Biochim. Biophys. Acta. 330 : 8-26, 1973.

3) Kobayashi,T., Tsukagoshi, S. and Sakurai, Y.: Enhancement of the cancer chemotherapeutic effect of cytosine arabinoside entrapped in liposomes on mouse leukemia L-1210. G.A.N.N., $66: 719-720,1975$.

4) Deamer, D. and Bangham, A.D. : Large volume liposomes by an ether vaporization method.Biochem. Biophys. Acta $443: 629-634$, 1976.

5) Papahadjopoulos, D., Vail, W.J., Jacobson, K. and Poste, G. : Cochleate lipid cylinders : Formation by fusion of unilamellar lipid vesicles. Biochim. Biophys. Acta. 394 : 483-491, 1975.

6) Huang, C.: Studies on phosphatidylcholine vesicles. Formation and physical characteristics. Biochemistry, 8: 344-352, 1969.

7) Haxby, J.A., Kinsky, C.B. and Kinsky, S.C. : Immune response of a liposomal modelmembrane. Proc. N.A.S., 61 : 300-307, 1968.

8) Mayhew, F., Papahadjopoulos, D., Rustum, Y. M. and Dave, C.: Inhibition of tumor cell growth in vitro and in vivo by 1-D-arabinofuranosylcytosine entrapped within phospholipid vesicles. Can. Res. 36 : 4406-4411, 1976. 
9) Papahadjopoulos, D., Poste, G., Vail, W.J. and Biedler, J.L. : Use of lipid vesicles as carriers to introduce actinomycin D into resistant tumor cells. Can. Res., 36 : 2988-2993, 1976.

10）藤田浩, 沢部孝昭, 土田裕子, 木村禧代二： Bleomycinの不活性化について. Chemotherapy, $18: 372-373,1970$.

11) Papahadjopoulos, G., Poste, G., Schaeffer, B.E. and Vail, W.J.: Membrane fusion and molecular segregation in phospholipid vesicles. Biochim. Biophys. Acta, 352 : 10-28, 1974.

12) Martin, F. and MacDonald, R.: Liposomes can mimic virus membranes. Nature, 252 : 161-163, 1974 .

13) Panano, R.E. and Takeichi, M. : Adhesion of phospholipid vesicles to chinese hamster fibroblast.J. Cell Biol., 74 : 531-546, 1977.

14) Weinstein, J.N., Yoshikami, S., Henkart, P., Blumenthal, R. and Hagins, W.A. : Liposomecell interaction: Transfer and intracellular release of a trapped fluorescent marker. Science, $195:$ 489-492, 1977.

15) Poste, G. and Papahadjopoulos, D.: The influence of vesicle membrane properties on the interaction of lipid vesicles with culture cells. Ann. N.Y. Acad. Sci., 309 : 164-184, 1978.

16) Papahadjopoulos, D., Poste, G. and Mayhew, E. : Cellular uptake of cyclic AMP captured within phospholipid vesicles and effect on cellgrowth behaviour. Biochim. Biophys. Acta. $363: 404-418,1974$.

17) McDougall, R., Dunnick, J.K., Goris, M.L. and Kriss, J.P.: In vivo distribution of vesicles loaded with radiopharmaceuticals: A study of different routes of administration. J. Nucl. Med., 16 : 488-491, 1975.

18) Dunnick, J.K., Badger, R.S., Takeda, T. and Kriss, J.P., : Vesicle interactions with antibody and peptide hormone. Role of vesicle composition. J. Nucl. Med., 17 : 1073-1076, 1976.

19) Uchida, T.: Reconstitution of lipid vesicles associated with HVJ (Sendai virus) spikes. Purification and some properties of vesicles containing non-toxic fragment A of diphteria toxin. J. Cell. Biol., 80: 10-20, 1979.
20) Yatvin, M.B., Muhlensiepen, H., Porschen, W., Weinstein, J.J. and Feinendegen, L.E. : Selective delivery of liposomeassociated cisdichlorodiammineplatinum (CDDP) by heat and its influence on tumor drug uptake and growth. Can. Res., 41 : 1602-1607, 1981.

21) Leserman, L.D., Weinstein, J.N., Moore, J.J. and Terry, W.D.: Specific interaction of myeloma tumor cells with hapten-bearing liposomes containing methotrexate and carboxyluorescein. Can. Res., 40 : 4768-4774, 1980.

22) Gregoriadis, G. and Neerujun, E.D. : Homing of liposomes to target cells. Biochem. Biophys. Res. Comm., 65 : 537-544, 1975.

23) Kataoka, T. and Kobayashi, T.: Enhancement of chemotherapeutic effect by entrapping 1-D-arabino-furano-sylcytosine in lipid vesicles and its mode of action. Ann. N.Y. Acad. Sci., 309: 387-394, 1978.

24) Kimelberg, H.K., Tracy,T.F., Biddlecome, S.M. and Bourke, R.S. : The effect of entrapment in liposomes on the in vivo distribution of ${ }^{3} \mathrm{H}$ methotrexate in a primate. Cancer Res., 36 : 2420-2957, 1976.

25) Rahman, Y., Cerny, E.A., Tollaksen, S.L., Wright, B.J., Nance, L.S. and Thomson, J.F. : Liposome-encapsulated actinomycin D : Potential in cancer chemotherapy. Proceedings of the Society for Experimental Biology and Medicine, 146 : 1173-1176, 1974.

26) Rahman, Y., Kisieleski, W.E., Busess, E.M. and Cerny, E.A.: Liposomes containing ${ }^{3} \mathrm{H}$ actinomycin D. Differential tissue distribution by varying the mode of drug incorporation. Europ. J. Cancer, 11 : 883-889, 1975.

27) Kaye, S.B., Boden, J.A. and Ryman, B.E. : The effect of liposome (phospholipid vesicle) entrapment of actinomycin $\mathrm{D}$ and methotrexate on the in vivo treatment of sensitive an resistant solid murine tumours. Europ. J. Cancer, 11 : 279-289, 1981.

28）曽根三郎, 螺良英郎, Fjidler, I.J. : 癌転移治療一人 工脂質膜（リポソーム）を用いた新しい試み一. Oncologia, 1:18-36, 1982. （1982年5月17日受付，特別掲載） 